\title{
Geochemistry of high-Mg andesites and adakitic andesite from the Sanchazi block of the Mian-Lue ophiolitic melange in the Qinling Mountains, central China: Evidence of partial melting of the subducted Paleo-Tethyan crust
}

\author{
JI-FENG XU, QIANG WANG and XUE-YUAN YU
}

Guangzhou Institute of Geochemistry, Chinese Academy of Sciences, Wushan, Guangzhou 510640, P.R. China

(Received December 17, 1999; Accepted July 26, 2000)

\begin{abstract}
Major and trace element and $\mathrm{Nd}$ and $\mathrm{Pb}$ isotopic compositions of volcanic rocks from the Sanchazi (SCZ) block of the Mian-Lue ophiolitic melange in the Qinling Mountains, central China were analyzed to provide insights into the subduction processes during the Late Paleozoic along the margins of the paleoTethyan ocean. All igneous rocks from the SCZ block show characteristics typical of arc volcanic rocks such as depletion in high field-strength elements (HFSE) and enrichment in large-ion-lithophile elements (LILE) relative to normal mid-ocean ridge basalts (N-MORB). Included among these arc rocks are high$\mathrm{Mg}$ andesites (HMAs) and an adakitic andesite. The adakitic andesite has a steep REE pattern, low Y and $\mathrm{Yb}$, and high $\mathrm{La} / \mathrm{Yb}$ values, which is similar to those of typical adakites derived by partial melting of subducted basaltic crust. The HMAs from the SCZ block also have adakitic affinities except that they have lower $\mathrm{La} / \mathrm{Yb}(\sim 10)$ and $\mathrm{Al}_{2} \mathrm{O}_{3}(<15$ wt.\%). Both the adakitic andesite and HMAs have higher $\mathrm{MgO}, \mathrm{Ni}$, and $\mathrm{Cr}$ contents than the normal andesites and basalts. The age-corrected $\mathrm{Nd}-\mathrm{Pb}$ isotopic compositions of the HMAs and adakitic andesite show an enriched isotopic signature relative to the MORB-type rocks in the Mianlue area, suggesting that the former probably contain components from sediments or continental crust materials. The data reveal that the adakitic andesite and HMAs in the SCZ block were most probably produced by partial melting of an eclogitic oceanic crust and/or subducted sediments, followed by interaction of the melt with the overlying mantle wedge, and finally by a possible contamination of the melt by the crustal materials. Our result infers that seafloor spreading was active in the paleo-Tethyan ocean, and an ancient island arc system was present along the proto-Qinling area in the Late Paleozoic. The paleoTethys ocean separated the South China and North China blocks in Late Paleozoic. The final integration between above two blocks is suggested to have occurred in the Triassic.
\end{abstract}

\section{INTRODUCTION}

It is widely believed that most arc magmas are derived from hydrous melting of peridotites in the mantle wedge induced by fluids released from the subducted lithosphere (e.g., Gill, 1981; Kushiro, 1990; Arculus, 1994). However, adakites and adakitic rocks in some modern island and continental arcs that were produced by partial melting of subducted basaltic crust have recently attracted great attention (e.g., Defant and Drummond, 1990; Drummond and Defant, 1990). A similar slab melting process is also proposed to play an important role in the formation of the Archaean crust (Drummond and Defant, 1990). Although typical adakites are dacitic in composition, adakitic andesites and related high-Mg andesites (HMAs) have also been detected in some arcs (e.g., in Baja California, southern Chile, and Aleutians-Rogers et al., 1985; Saunders et al., 1987; Kay et al., 1993; Yogodzinski et al., 1995; Yogodzinski and Kelemen, 1998). Apparently, the components from slab melting can not only directly produce arc volcanic rocks (i.e., adakites), but also influence the production of HMAs and adakitic andesite (Yogodzinski et al., 1994, 1995; Yogodzinski and 
Kelemen, 1998; Stern and Kilian, 1996). For example, recent investigations emphasized the contribution of melts from subducted lithosphere in the formation of high-Mg (or $\mathrm{Mg}$-) andesites (Yogodzinski et al., 1995; Yogodzinski and Kelemen, 1998; Shinjo, 1999). Thus, partial melting of a subducted oceanic basaltic crust and interaction of the melt generated with the overlying mantle wedge is increasingly becoming popular as a model for the formation of HMAs and adakitic andesites.

Although most adakite and adakitic rocks are thought to be related to the partial melting of subducted oceanic crust, there are still some rocks with adakitic feature to be argued other origin interpretation, e.g., partial melting of mafic rock in lower crust (Atherton and Petford, 1993; Barnes et al., 1996), AFC process of basaltic magma (Castillo et al., 1999). Recently, Shimoda et al. (1998) forwarded that the Setouchi HMAs with adakitic compositional signature has a significant components attributed from partial melting of subducted sediments. Thus, adakites and the rocks with adakitic compositional feature probably have multiple origins, and the identification of the origin of adakitic rocks is of important scientific significance.

So far, studies of adakites and adakite-related volcanic rocks mostly focus on modern arcs and Archaean terranes. Here we report an adakitic andesite and the associated high- $\mathrm{Mg}$ andesites of Late Paleozoic age found in a tectonic block within the Paleo-Tethyan ophiolitic melange in the Qinling orogenic belt, Central China. It must be noted that geological history of the Qinling orogen and the timing of collision between the South and North China block (craton) have been controversial. Two different issues on the timing of collision have been proposed-e.g., the middle Paleozoic (Gao et al., 1995); and the Triassic (Li et al., 1996; Zhang et al., 1996). The presence of the Mian-Lue Tethyan ophiolitic melange (Xu et al., 1994, 1998; Zhang et al., 1995, 1996) and the related arc volcanic rocks found in this belt (Xu et al., 1998; Lai et al., 1998) indicate that an ancient ocean-arc system possibly occurred in
Qinling area, Central China in the Late Paleozoic (Feng et al., 1996). The high-Mg and adakitic andesites reported in this paper indeed confirm that subduction of an ancient oceanic lithosphere in the Qinling area occurred in the Late Paeozoic, further indicating that the South and North China block were still separated at that time. Thus, this study also provides important information on the tectonic evolution of the Qinling and Dabieshan orogenic belts.

The main objective of this study is to better understand the arc magmatic processes attendant to the subduction of the Paleo-Tethyan $(\sim 350$ M.Y.) oceanic lithosphere in the Late Paleozoic. Specifically, this paper is to (1) present the geochemical characteristics of adakitic andesite and high-Mg andesites, (2) propose a model for the origin of the adakitic andesite and high- $\mathrm{Mg}$ andesites, and (3) provide the information on integration process between the North and South China block (craton).

\section{Geological SetTing}

The Qinling orogen is located in Central China and connect eastward to the Dabieshan orogen that bears ultra-high pressure metamorphic rocks, which separates the North China block from the South China block (Fig. 1). In the Qinling area, the North and South Qinling orogens were, respectively, regarded as the southern margin of the North China block and the northern margin of the South China block. It was believed that the South and North China blocks collided along the Sangdan suture zone that lined the South Qinling and North Qinling orogens. In recent years, an important discovery of an ophiolitic and tectonic melange in the Mian-Lueyang area (or call the Mian-Lue belt) in the southwest region of South Qinling orogen (Xu et al., 1994, 1998; Xu and Han, 1996; Zhang et al., 1995, 1996; etc.) has fueled interests in the orogenic evolution of the Qinling area.

The Mian-Lue ophiolitic and tectonic melange consists of a series of ophiolite blocks, arc volcanic rock blocks, meta-sedimentary rock blocks, 




Fig. 1. Tectonic framework of Qinling orogen and adjacent South China and North China blocks (cratons), and geological map of the Sanchazi volcanic arc block in the Mian-Lue ophiolitic and tectonic melange. MLB: MianLue ophiolitic and tectonic suture belt, SDB: Shang-Dan suture belt, South Qinling: the South Qinling orogenic belt, North Qinling: the North Qinling orogenic belt. 1. serpentinized harzburgite; 2. N-NORB-type rocks; 3. Sanchazi arc volcanic rock; 4. meta-sedimentary rocks; 5. siliceous rock with radiolarians fauna; 6. Qiaozigou volcanic rock block; 7. fracture; 8. other blocks in Mian-Lue melange.

and basement metamorphic blocks. The ophiolitic blocks were termed as the Mian-Lue North ophiolite (MLNO) (Xu et al., 1994, 1998). The geochemistry and $\mathrm{Nd}$ and $\mathrm{Pb}$ isotopic composition of a typical ophiolite in the MLNO, the Hunshuiguan-Zhuangke block, have been studied in detail by Xu et al. (2000). The studies indicated that a possible paleo-ocean represented by the MLNO was formed during the Late Paleozoic (Xu and Han, 1996; Xu et al., 1998; Zhang et al., 1995; Feng et al., 1996). This Late Paleozoic paleoocean is thought to be a part of paleo-Tethys that was possibly connected southwestward to the typical Sanjiang paleo-Tethys (Xu and Han, 1996; Xu et al., 1998), and extended eastward to the Suizhou-Jingshan area on the southern side of the Dabieshan orogen where similar ophiolite blocks have also been found (Dong et al., 1999). On the 
other hand, some studies showed that the MianLue ophiolitic and tectonic melange belt was produced by the collision of the South China block and South Qinling orogen in the Triassic that were previously separated by the Tethyan ocean in the Late Paleozoic (Zhang et al., 1995, 1996). Two different tectonic models for the Mian-Lue belt have been forwarded-one model proposes that the Mian-Lue Tethys was only an extinct basin above continental basement (Zhang et al., 1995; Li et al., 1996), whereas the other model posits that Paleo-Tethys is a full-scale ocean with a trench-oceanic-arc system (Xu et al., 1998; Lai et al., 1998).

Arc volcanic rocks have been found in the Mian-Lue ophiolitic and tectonic melange belt (Xu et al., 1998; Lai et al., 1998). Of the arc volcanic rock blocks, the Sanchazi block (hereafter call the SCZ block) is the most typical. The SCZ block is located in the Sanchazi area of Lueyang county, to the west of the Hunshuiguan-Zhuangke ophiolitic block (Fig. 1). These two blocks are separated by a major fault. The SCZ block is mainly composed of mafic igneous rocks and a few peridotite slices as well as some meta-sedimentary rocks. The mafic igneous rocks can be divided into two groups based on their texturecoarse-grained and fine-grained mafic rocks. The former are meta-gabbros and meta-diorites, and the latter are arc meta-basalts and meta-andesites. These arc volcanic rocks underwent greenschistfacies metamorphism. Almost all the original igneous mineral were replaced by a metamorphic mineral assemblage (e.g., albite-chlorite-epidotequartz), except for a small amount of original phenocrystic phases (e.g., $\mathrm{Hb}$ and $\mathrm{Pl}$ ) that are still preserved in a few relatively coarse-grained andesitic rocks. Geochemical feature of rocks in the block is also clearly distinct from that of the igneous rocks in the Hunshuiguan-Zhuangke ophiolitic block that have normal seafloor basaltic affinity (Xu et al., 1998, 2000), suggesting that rocks in the SCZ block were derived in a paleo island arc environment (see below).

The exact isotopic-age of SCZ arc volcanic rocks has not been determined yet. Li et al. (1996) reported Sm-Nd whole rock isochron age (242 Ma) of the volcanic rocks from the Heigouxia Valley ophiolitic block in the Mian-Lue belt close to the SCZ block, but suggested that it might represent the metamorphic age. Therefore, volcanic rocks among ophiolitic and arc-origin blocks in the Mian-Lue belt were most likely generated prior to $242 \mathrm{Ma}$. In addition, siliceous sedimentary rocks of possible deep-water origin (Fig. 1) and with the Early Carboniferous radiolarians fauna (e.g., Albaillella sp.; Latentifistula cf. ruestae; Entactinia variospina) within the Mian-Lue melange have also been discovered close to the SCZ block (Feng et al., 1996). The age of these fossils infers that the paleo-Tethyan oceanic basin and related paleo-island arc existed in the Mian-Lue area in about the Early Carboniferous ( $\mathrm{Xu}$ and Han, 1996; Xu et al., 1998; Feng et al., 1996). In summary, the age of ancient SCZ arc is probably at $\sim 350 \mathrm{Ma}$ (Early Carboniferous).

\section{SAMPle AND ANALYTiCAL MethodS}

All samples studied here were collected in the Pianqiaogou valley and along the two sides of the Kang-Lue highway that cut across the SCZ block. They were metamorphosed to greenschists rocks and some rocks also show slight calcareous alteration. All samples were examined under the microscope and then grouped accordingly into different rock types. From each rock type, only the least-altered representative samples were selected for analyses. The samples chosen were first split into small chips and soaked in the $4 \mathrm{~N}$ hydrochloric acid for one hour in order to leach out secondary carbonate minerals, and then powdered. The powders were measured by gravimetry and AAS for their major element compositions (analytical procedure described by Gao et al., 1995). Trace elements, including the rare earth element (REE), were analyzed by inductively coupled mass spectrometry (ICP-MS) at the Guangzhou Institute of Geochemistry, Chinese Academy of Sciences. The analytical procedure for the ICP-MS analysis is similar to that described by Li (1997). Trace element concentrations were drift corrected 
using the standard sample BCR-1; analytical uncertainties are generally better than $5 \%$ for most elements but $10 \%$ for other several elements. $\mathrm{Nd}$ and $\mathrm{Pb}$ isotopic ratios of the rocks were analyzed on VG 354 Thermal Ionization mass spetrometer (TIMS) also at the Guangzhou Institute of Geochemistry. The analytical procedure for TIMS is described in detail by $\mathrm{Li}$ and McCulloch (1998). $\mathrm{Nd}$ isotopic ratios were measured in metal form, mass fractionation corrected to ${ }^{146} \mathrm{Nd} /{ }^{144} \mathrm{Nd}=$ 0.7219 and are reported relative to ${ }^{143} \mathrm{Nd} /{ }^{144} \mathrm{Nd}=$ 0.511860 for the La Jolla Standard. Analytical uncertainty for ${ }^{143} \mathrm{Nd} /{ }^{144} \mathrm{Nd}$ measurements is $+/-2$ sigma. $\mathrm{Pb}$ isotopic ratios were corrected for mass fractionation using replicate analyses of the standard NIST SRM 981 and using the values of Todt et al. (1984); the analytical precision are about \pm 0.005 for ${ }^{206} \mathrm{~Pb} /{ }^{204} \mathrm{~Pb}$ and ${ }^{207} \mathrm{~Pb} /{ }^{204} \mathrm{~Pb}$ and


Th U Nb La Ce Sr Nd Hf Zr Sm Eu Ti Gd Dy Y Yb Lu

Fig. 2. REE and incompatible trace element diagram of arc volcanic rocks from the SCZ block. a, REE pattern; $b$, trace element pattern, which only shows those alteration-resistant incompatible elements and the mobile element-Sr. The adakitic andesite shows the lowest HREE contents among all arc volcanic rocks in the SCZ block. The adakite from the Cook Island (Stern and Kilian, 1996) and Adak-type Mg-andesite from the West Aleutiani (Yogodzinski et al., 1995) are shown in the figure for comparison. Normalizing values of the Chondrite and Primary mantle are after Sun and McDonough (1989). 
\pm 0.01 for ${ }^{208} \mathrm{~Pb} /{ }^{204} \mathrm{~Pb}$. The total procedural blanks are $\mathrm{Sm}<5 \times 10^{-11} \mathrm{~g}, \mathrm{Nd}<2 \times 10^{-10} \mathrm{~g}$ and $\mathrm{Pb}<$ $2 \times 10^{-10} \mathrm{~g}$.

\section{Alteration Effect}

Although the basalts and andesites from the SCZ block are altered in different degree and slightly metamorphozed, their contents of alteration-resistant trace elements show coherent, subparallel concentration patterns except mobile element-Sr (Fig. 2). These consistent patterns indicate that in general the samples still may preserve the bulk of their original alteration-resistant trace element composition. This inference is consistent with previous studies which showed that the concentration of some of the trace elements such as the high field-strength elements (HFSE) and rare earth elements (REE) in igneous rocks is not generally affected by rock alteration (e.g., Ludden and Thompson, 1978; Bienvenu et al., 1990). However, it is possible that some mobile elements ( $\mathrm{K}, \mathrm{Rb}, \mathrm{Ba}, \mathrm{Sr}$, etc.) have been mobilized by alteration and metamorphism. Thus, we will only use the alteration-resistant elements, i.e., HFSE and REE, in the discussion below. In addi- tion, previous studies have also shown that only severe seawater alteration can affect the ${ }^{143} \mathrm{Nd} /$ ${ }^{144} \mathrm{Nd}$ ratios of oceanic rocks (e.g., Cheng et al., 1987; McCulloch et al., 1981) because seawater is extraordinary low in $\mathrm{Nd}\left(4 \times 10^{-6} \mathrm{ppm}-\right.$ Mahoney et al., 1998). Similar to Nd isotopic ratios, $\mathrm{Pb}$ isotopic ratios of oceanic rocks are generally not affected by sea-water alteration because the $\mathrm{Pb}$ content of seawater is also low $\left(2 \times 10^{-6}\right.$ ppm-Mahoney et al., 1998). Thus, we believe that the $\mathrm{Nd}, \mathrm{Pb}$ isotopic ratios of our samples reported here may not be modified by alteration/ metamorphism and may most probably represent original isotopic signature of these rocks.

\section{GeOChemical Results}

Major and trace elements data of representative samples from the SCZ block are given in Table 1. In the SCZ block, two kinds of fine- and coarse-grained mafic rocks were identified based solely on their $\mathrm{SiO}_{2}$ contents-andesitic and basaltic rocks, with the former volumetrically dominant over the latter. All the basaltic and andesitic rocks belong to the calc-alkaline rock series because they are plotted in a calc-alkaline trend on

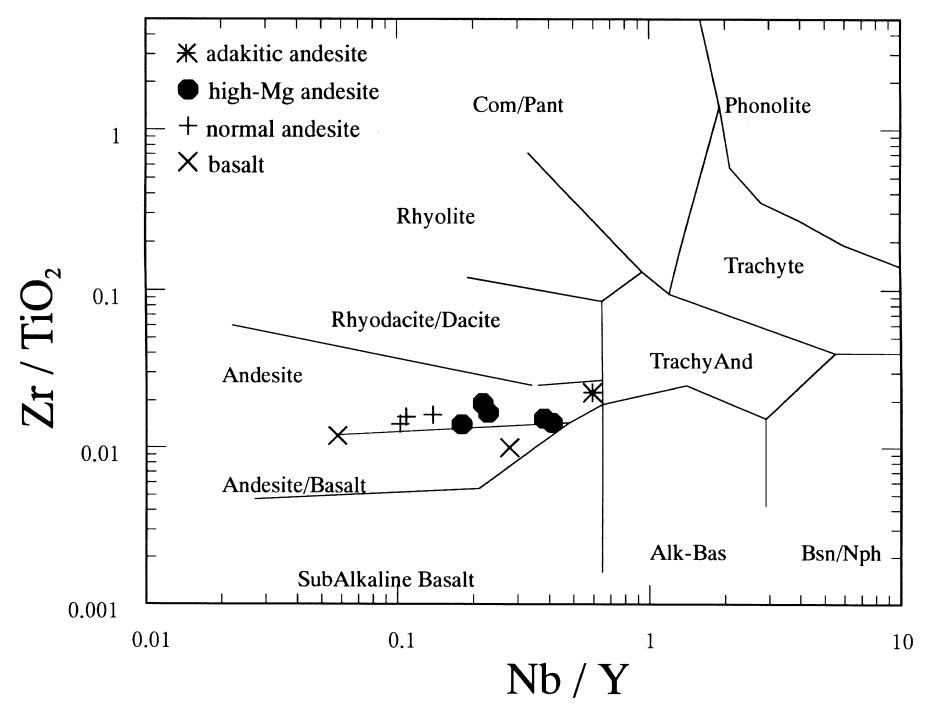

Fig. 3. $\mathrm{Nb} / \mathrm{Y}-\mathrm{Zr} / \mathrm{TiO} \mathrm{O}_{2}$ classifications for rocks from the SCZ block, original diagram is after Winchester and Floyd (1976). 

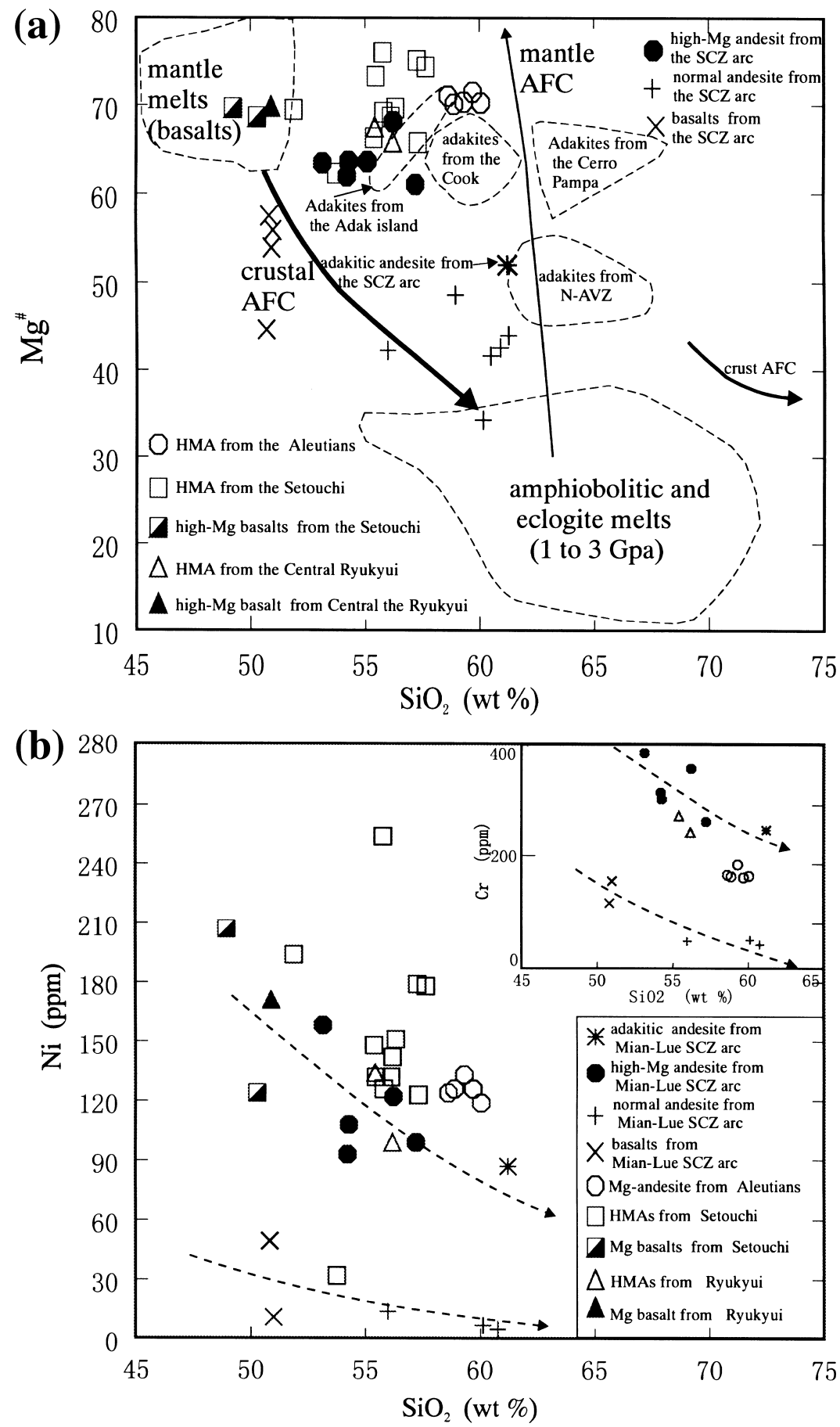

Fig. 4. $\mathrm{Mg \# ,} \mathrm{Cr}$ and $\mathrm{Ni}-\mathrm{SiO}_{2}$ diagram for the volcanic rocks from the $\mathrm{SCZ}$ block. In $\mathrm{Cr}$, Ni and $\mathrm{Mg \# -SiO}$ diagrams, adakitic and high-Mg andesites show a compositional trend distinctive from basalts and normal andesites in the SCZ block, suggesting that they are derived from the sources different from the latter. The original diagram of $\mathrm{Mg \# -SiO}$ is after Stern and Kilian (1996). Several data of SCZ samples are from Lai et al. (1998). Data of Mg-andesites of the Aleutians are after Yogodzinski et al. (1995). Data of HMAs from the Setouch are after Shimoda et al. (1998). Data of high-Mg andesites in the Central Ryukyui are after Shinjo (1999). 
Alk-FeO-MgO diagram (not shown). Because of alteration and metamorphic effects, the $\mathrm{Nb} / \mathrm{Y}$ vs. $\mathrm{Zr} / \mathrm{TiO}_{2}$ classification schemes (Fig. 3) of Winchester and Floyd (1976) were used to verify the rock names, which indicated that they were basalts and andesites (Fig. 3). Furthermore, the andesites $\left(\mathrm{SiO}_{2}>53\right.$ wt.\%) in the $\mathrm{SCZ}$ block, can further be divided into two subgroups-highmagnesian (or magnesian) andesite and normal andesite based on the definition of Crawford et al. (1989) on high-Mg andesite and boninite. The high-Mg andesites (HMAs) characteristically have higher $\mathrm{Mg} \#(\mathrm{Mg} /[\mathrm{Mg}+\mathrm{Fe}]>0.6)$ and $\mathrm{Cr}$, Ni concentration (Fig. 4) than normal andesites in the SCZ block and other modern island arcs (Kushiro, 1990; Arculus, 1994). The MgO contents of the HMAs from the SCZ block are similar to those of well-studied Setouchi HMA suite from Japan (Tatsumi and Ishizaka, 1982), although the former have slightly lower $\mathrm{Mg \#}$ content than the latter does.

One sample stands out from the normal andesite group in the SCZ block. This sample (\#106, Table 1) has relatively lower MgO content than the HMAs but has clearly higher MgO (Fig. 4) than the rest of the normal andesites in the SCZ block. Its geochemical characteristic is uniquely comparable to that of typical adakite that is widely believed to represent melt derived from melting of subducted oceanic crust (e.g., Defant and Drummond, 1990; Stern and Kilian, 1996). For example, sample 106 has high $\mathrm{La} / \mathrm{Yb}$ (22.3), $\mathrm{Al}_{2} \mathrm{O}_{3}$ (17.37); low Y (11 ppm), Yb (1.01 ppm). It shows the most steep LREE pattern of all the igneous rocks in the SCZ block (Fig. 2) and plotted in the compositional evolution trend of the high-Mg andesite on $\mathrm{SiO}_{2}$ vs. $\mathrm{Cr}, \mathrm{Ni}, \mathrm{MgO}$ diagrams (Fig. 4), indicating that it most likely has an genetic relation with the high- $\mathrm{Mg}$ andesites. In addition, sample 106 also has higher $\mathrm{Cr}$, Ni contents distinct from arc basalts and normal andesites in the SCZ block which fall in another a compositional trend (Fig. 4), suggesting that it is not probably formed by direct partial melting of hydrous mantle wedge or arc basaltic magma differentiation beneath the SCZ subduction zone. Thus, this sam-

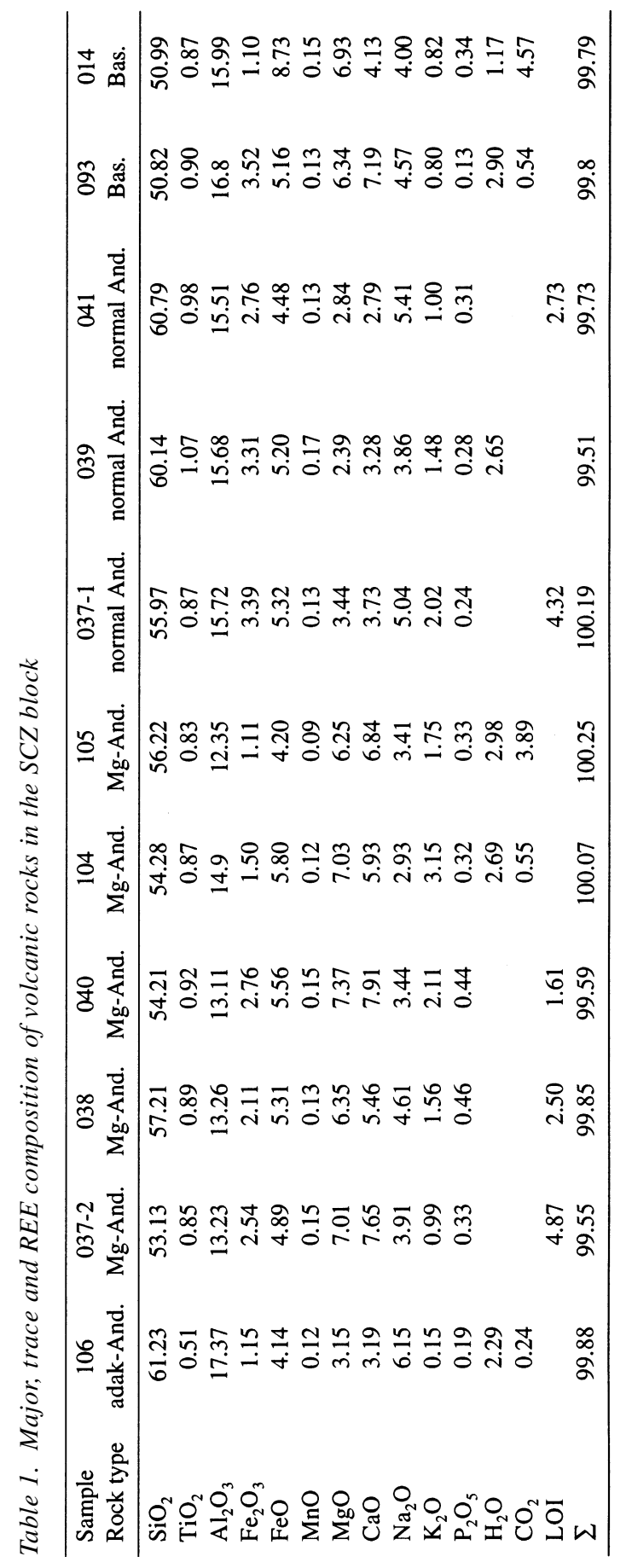




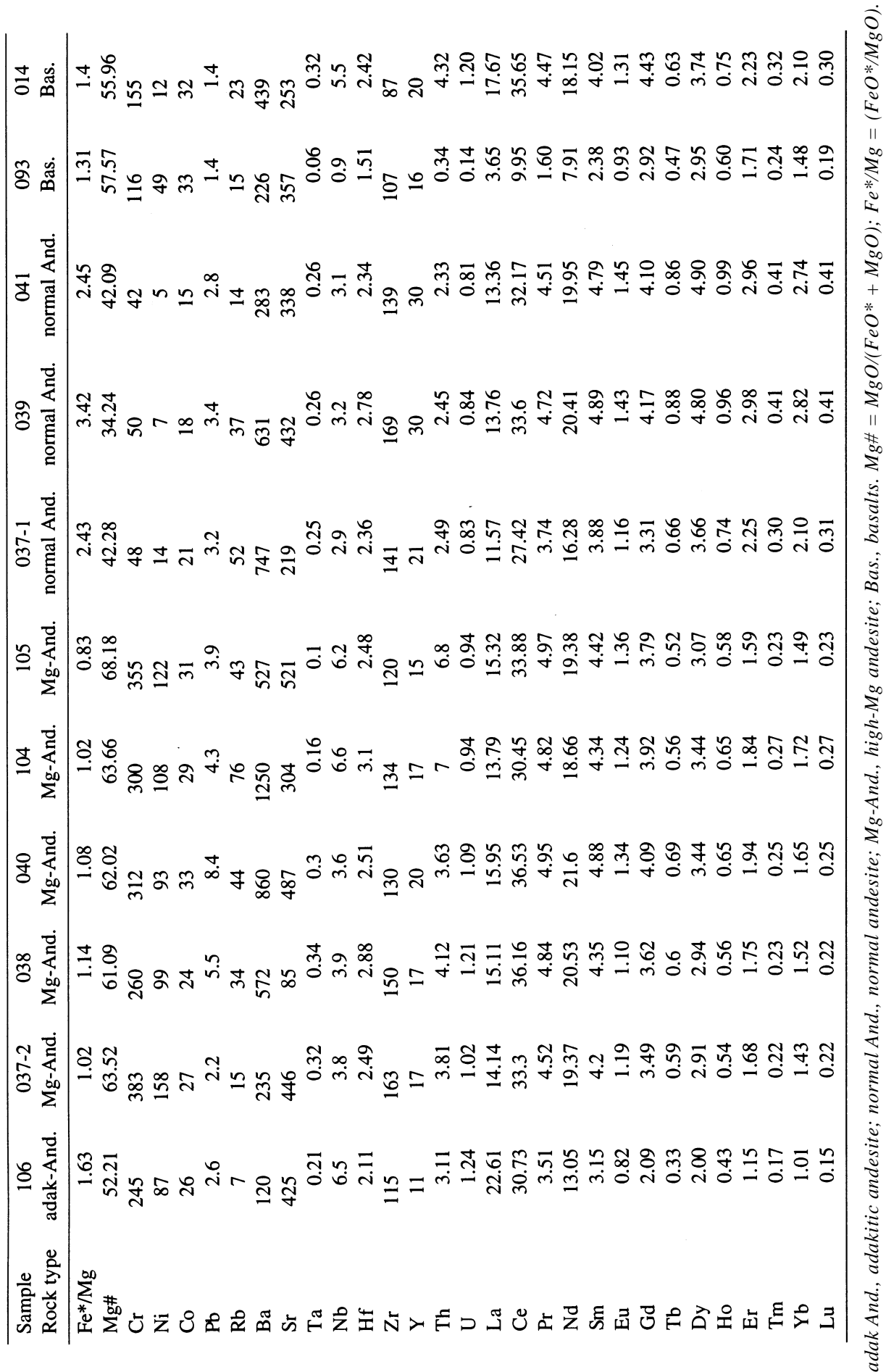


ple is most probably related to adakitic melt from subducted oceanic crust or sediment (see below). In this study, we call it "adakitic andesite" because it is really an andesite, although it has some of the geochemical characteristics of adakite which generally is a dacite ( $>62 \mathrm{wt} . \% \mathrm{SiO}_{2}$ ). The adakitic andesite represents a small volume of outcrops within the SCZ block, however it is closely associated in time and space with the HMAs. The HMAs in the SCZ block, in turn, also share most of the geochemical features with an adakite (e.g., low Y, Yb, see Table 1) except relatively low $\mathrm{Al}_{2} \mathrm{O}_{3}$ (<15 wt.\%) and La/Yb (9-10).

Chondrite-normalized REE patterns for the SCZ block samples are shown in Fig. 2a. As mentioned earlier, the adakitic andesite is the most strongly LREE-enriched and HREE-depleted of the samples in SCZ block, showing a rather steep REE pattern much similar to typical adakites (Defant and Drummond, 1990). The HMAs in the SCZ block exhibit moderate enrichment in LREE, about the same REE concentration and distribution pattern of Setouchi HMAs (Tatsumi and Ishizaka, 1982). In contrast, normal andesites from the SCZ block only show slightly LREE enrichment and almost without any HREE depletion.

On primary mantle-normalized trace element spider diagram (Fig. 2b), all the rocks display depletion in high field strength elements (HFSE$\mathrm{Nb}$, Ti, Hf, and Ta, but Ta not shown in Fig. 2) as compared to primary mantle, which is a typical signature of arc volcanic rocks, confirming that these rocks from the SCZ block are indeed produced in a convergent margin environment. The

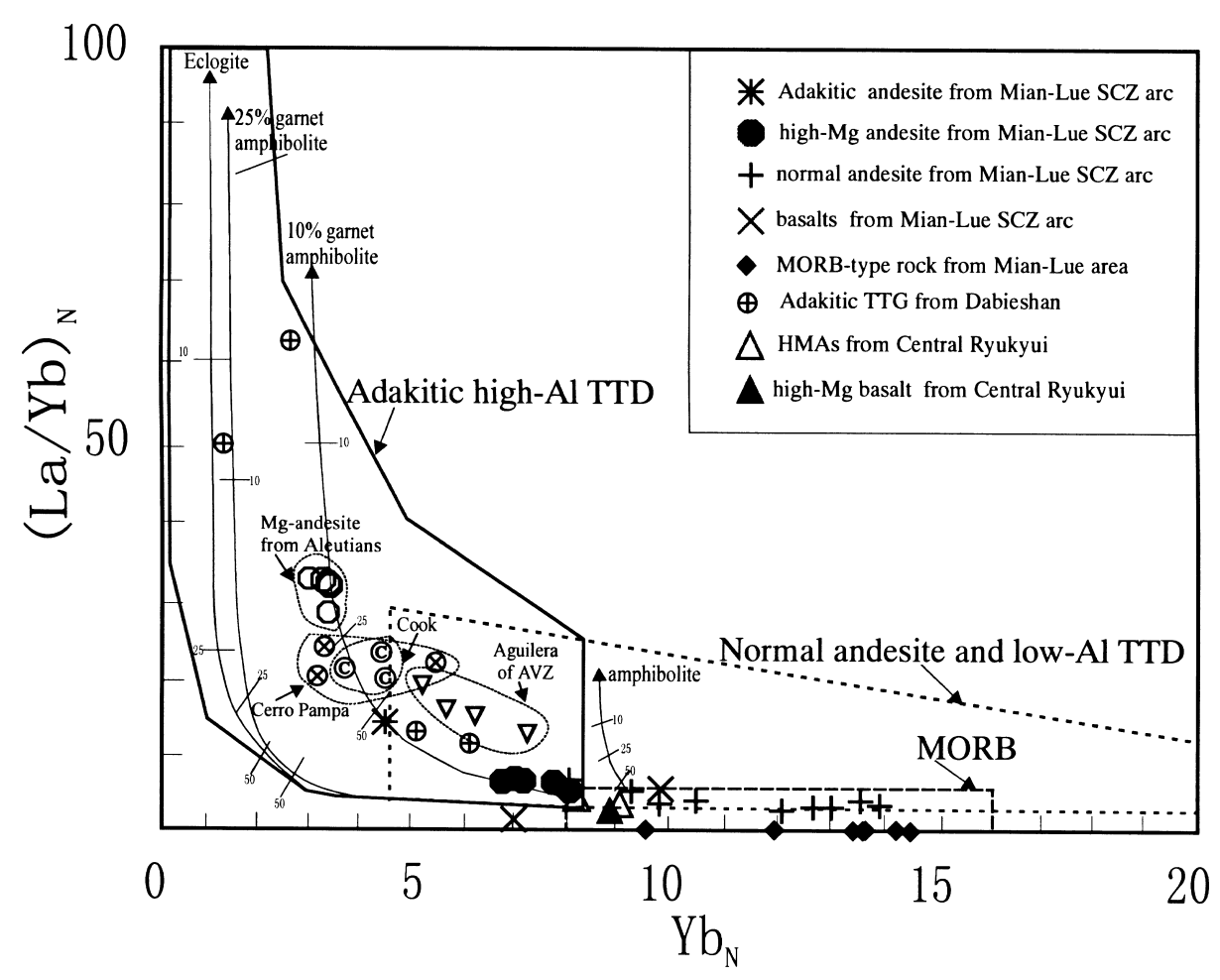

Fig. 5. $(L a / Y b)_{N}$ vs. $(Y b)_{N}$ diagram for the adakitic and high-Mg andesites from the SCZ block. The original diagram is after Drummond and Defend (1990). Some typical adakites and Adak-type high-Mg andesites are plotted on this figure for comparison (Cook island-Stern and Kilian, 1996; Cerro Pampa-Kay et al., 1993; Central Ryukyui-Shinjo, 1999; western Aleutians-Yogodzinski et al., 1995; Aguilera of AVZ-Stern and Kilian, 1996). The MORB-type rocks from ophiolitic block in the Mina-Lue belt are after Xu et al. (1998). Adakitic gneiss from the Dabieshan are after Wang and Xu et al. (2000). 
trace elemental features of the adakitic andesite and the HMAs in the SCZ block are similar to that of the adakitic rocks and Adak-type $\mathrm{Mg}$-andesites from the Cook island and Aleutians (Stern and Kilian, 1996; Yogodzinski et al., 1995) except various $\mathrm{Sr}$ concentration in Fig. 2.

In the $(\mathrm{La} / \mathrm{Yb})_{\mathrm{N}}$ vs. $(\mathrm{Yb})_{\mathrm{N}}$ diagram (Fig. 5), adakitic andesite and HMA from the SCZ block plot within the typical adakitic high-Al TTD field. They show a compositional signature very close to those of the typical adakites and adak-type $\mathrm{Mg}$ andesite from the Cook island, N-AVZ, and Aleutians on Fig. 5. (Stern and Kilian, 1996; Yogodzinski et al., 1995). In contrast, the plots of normal andesites from the SCZ block are far from those of the typical adakites and fall in the com- position field of normal arc andesite/Low-Al TTD (Fig. 5). The MORB-type rocks from the typical ophiolitic block in the Mian-Lue belt are plotted in Fig. 5 for comparison, they fall in the typical MORB field.

Four samples from the SCZ block were analyzed for their $\mathrm{Nd}$ and $\mathrm{Pb}$ isotopic ratios (Table 2 and Fig. 6). The samples show a large agecorrected isotopic compositional range-the low age-corrected $\mathrm{Pb}$ isotopic ratios are similar to those of the MORB-type rocks in the Mian-Lue belt, but the age-corrected $\mathrm{Nd}$ isotopic ratios are clearly lower than those of the latter. Of all the samples studied in this paper, one basalt sample (\#093) has the highest $\left({ }^{208} \mathrm{~Pb} /{ }^{204} \mathrm{~Pb}\right)_{t=350 \mathrm{Ma}}$ ratio and $\varepsilon_{\mathrm{Nd}(350 \mathrm{Ma})}$ values. Whereas, the adakitic

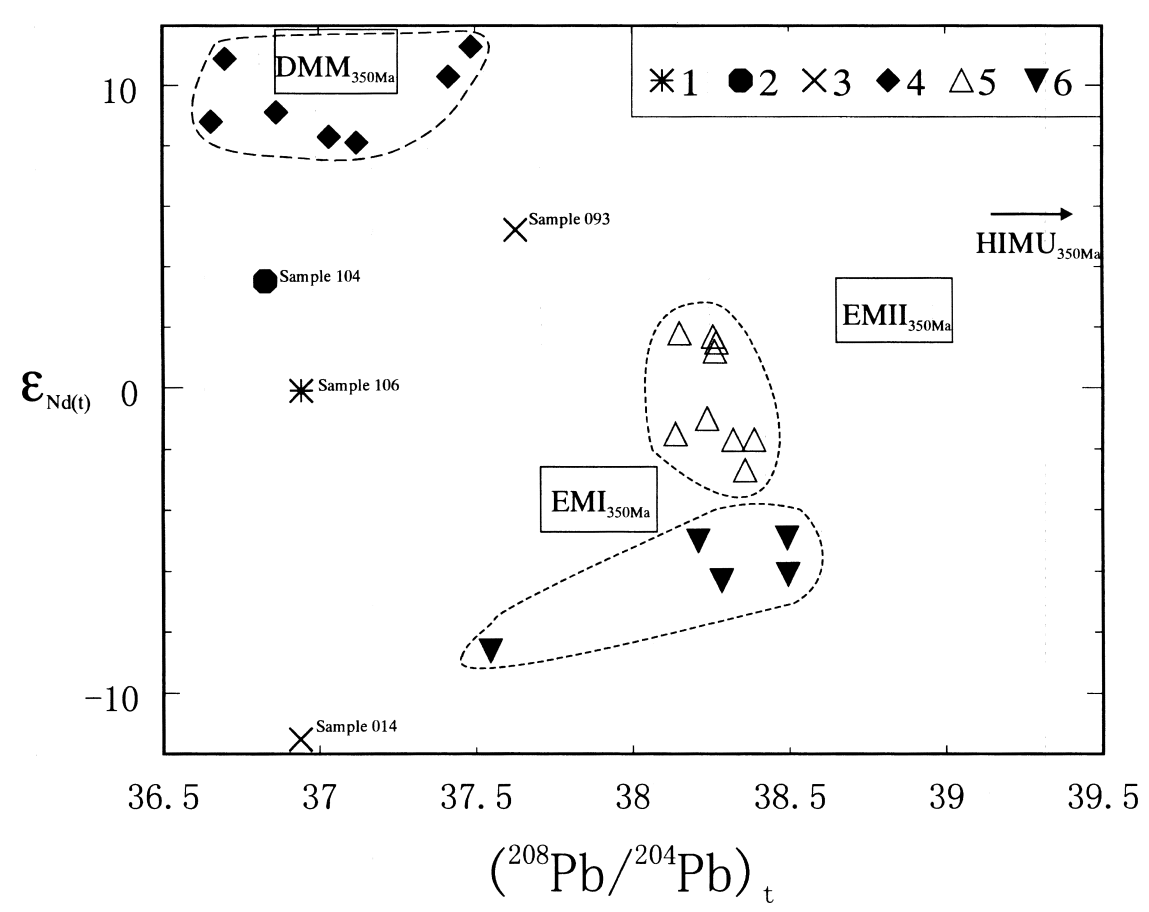

Fig. 6. $\varepsilon_{N d(t=350 M a)}$ vs. $\left({ }^{208} \mathrm{~Pb} /{ }^{204} \mathrm{~Pb}\right)_{t}$ diagram for the adakitic and high-Mg andesites from the SCZ block. $\varepsilon_{N d(t)}$ and age-corrected $\mathrm{Pb}$ isotopic ratios were calculated using $t=350 \mathrm{Ma}$. The adakitic and high-Mg andesite from the SCZ block show an enriched isotopic signature. The high-Mg andesites from the Setouch and sediments from the Philippine sea (Shimoda et al., 1998) are also plotted for comparison. Their isotopic ratios are also corrected to 350 Ma. N-MORB-type rocks in the Mian-Lue ophiolite are from Xu et al. (2000). DMM, EM1 and EM2 are mantle end-members (Zindler and Hart, 1986) and their values are also corrected to $350 \mathrm{Ma}$. Symbol signification on the figure: 1. Adakitic andesite of the SCZ arc block; 2. HMA of the SCZ arc block; 3. basalts of the SCZ arc block; 4. N-MORB-type rocks of the Mian-Lue ophiolitic block; 5. HMAs from Setouch; 6. Sediments from the Philippine sea. 
Table 2. Pb and Nd isotopic data of volcanic rocks in the SCZ block

\begin{tabular}{|c|c|c|c|c|c|}
\hline Sample & 104 & 106 & 093 & 014 & 014 (repeat) \\
\hline Rock type & high-Mg andesite & adakite & basalt & basalt & basalt \\
\hline $\mathrm{U}$ & 0.94 & 1.24 & 0.14 & 1.20 & 1.17 \\
\hline Th & 7.00 & 3.11 & 0.34 & 4.32 & 4.31 \\
\hline $\mathrm{Pb}$ & 4.3 & 2.6 & 1.4 & 1.4 & 1.6 \\
\hline${ }^{238} \mathrm{U} /{ }^{204} \mathrm{~Pb}$ & 13.9 & 30.3 & 6.3 & 56.7 & 47.7 \\
\hline${ }^{232} \mathrm{Th} /{ }^{204} \mathrm{~Pb}$ & 107.5 & 78.4 & 15.7 & 210.9 & 181.6 \\
\hline${ }^{206} \mathrm{~Pb} /{ }^{204} \mathrm{~Pb}$ & $18.646 \pm 0.010$ & $18.552 \pm 0.010$ & $17.855 \pm 0.010$ & $19.782 \pm 0.020$ & $19.765 \pm 0.018$ \\
\hline${ }^{207} \mathrm{~Pb} /{ }^{204} \mathrm{~Pb}$ & $15.599 \pm 0.010$ & $15.541 \pm 0.010$ & $15.570 \pm 0.010$ & $15.666 \pm 0.019$ & $15.653 \pm 0.015$ \\
\hline${ }^{208} \mathrm{~Pb} /{ }^{204} \mathrm{~Pb}$ & $38.707 \pm 0.030$ & $38.313 \pm 0.021$ & $37.903 \pm 0.010$ & $40.107 \pm 0.041$ & $40.009 \pm 0.037$ \\
\hline$\left({ }^{206} \mathrm{~Pb} /{ }^{204} \mathrm{~Pb}\right)_{t=350 \mathrm{Ma}}$ & 17.867 & 16.864 & 17.506 & 16.618 & 17.103 \\
\hline$\left({ }^{207} \mathrm{~Pb} /{ }^{204} \mathrm{~Pb}\right)_{t=350 \mathrm{Ma}}$ & 15.557 & 15.451 & 15.551 & 15.497 & 15.511 \\
\hline$\left({ }^{208} \mathrm{~Pb} /{ }^{204} \mathrm{~Pb}\right)_{t=350 \mathrm{Ma}}$ & 36.829 & 36.943 & 37.629 & 36.422 & 36.833 \\
\hline $\mathrm{Sm}$ & 4.263 & 3.15 & 2.277 & 3.858 & \\
\hline $\mathrm{Nd}$ & 18.272 & 13.05 & 7.621 & 17.627 & \\
\hline${ }^{147} \mathrm{Sm} /{ }^{144} \mathrm{Nd}$ & 0.1411 & 0.1468 & 0.1807 & 0.1323 & \\
\hline${ }^{143} \mathrm{Nd} /{ }^{144} \mathrm{Nd}$ & $0.512510 \pm 8$ & $0.512706 \pm 11$ & $0.512873 \pm 12$ & $0.511903 \pm 17$ & \\
\hline$\varepsilon_{\mathrm{Nd}(t=350 \mathrm{Ma})}$ & 3.52 & -0.05 & 5.26 & -11.5 & \\
\hline
\end{tabular}

$U$, Th and Pb concentration were analyzed by ICP-MS; Sm, Nd and isotopic ratios were measured through isotopic dilution. Age-corrected isotopic ratios were calculated using $t=350 \mathrm{Ma}$.

andesite and HMA have lower $\left({ }^{208} \mathrm{~Pb} /{ }^{204} \mathrm{~Pb}\right)_{t=350 \mathrm{Ma}}$ ratios and $\varepsilon_{\mathrm{Nd}(350 \mathrm{Ma})}$ values than the basalt (\#093) does. It must be noted that the adakitic and high$\mathrm{Mg}$ andesites show an enriched $\mathrm{Nd}$ isotopic signature, which is distinctive from the typical adakite and adak-type $\mathrm{Mg}$-andesites from the Cook island and Aleutians that generally have the depleted isotopic composition of MORB (Yogodzinski et al., 1995; Stern and Kilian, 1996; Kay et al., 1993). They also exhibit obviously lower $\varepsilon_{\mathrm{Nd}(350 \mathrm{Ma})}$ values than those of the MORBtype rocks from the ophiolitic block in the MianLue belt (Fig. 6). On the other hand, the SCZ HMA and adakitic andesite have the enriched isotopic composition similar to that of the Setouchi HMAs (Shimoda et al., 1998), except that the former have lower age-corrected $\mathrm{Pb}$ isotopic ratios. The Sample 093, 104 and 106 are plotted in the field (Fig. 6) between MORB-type rocks with depleted-isotopic feature from the ophiolitic block in the MianLue belt and sediments with enriched isotopic feature from Philippine Sea. However, another basalt sample (\#014) has very low $\varepsilon_{\mathrm{Nd}(350 \mathrm{Ma})}$ values. It is not clear yet why it shows even more enriched $\mathrm{Nd}$ isotopic signature than the sediments from Philippine Sea. A possible reason is that $\mathrm{Nd}-\mathrm{Pb}$ isotopic system of the sample 014 may be changed by sea-water alteration or it may be derived from an extremely enriched mantle source.

\section{Discussion}

Some investigators believe that adakites from the Cook Island, Cerro Pampa, Mount St. Helens originate from partial melting of subducted oceanic basalts beneath a subduction zone with a little or no mantle wedge contribution (Stern and Kilian, 1996; Kay et al., 1993; Defant and Drummond, 1993). However, others believe that some rocks with adakitic geochemical features may also form via water-undersaturated partial melting of the underplated mafic lower crust or previously subducted oceanic crust (Atherton and Petford, 1993; Peacock et al., 1994; Barnes et al., 1996). Recently, Castillo et al. (1999) also suggest that some arc volcanic rocks with adakitelike geochemical characteristics in the Central Mindanao Arc in southern Philippines can be derived from normal arc magmas by the combined process of shallow level crust assimilation and fractional crystallization (AFC) and have negligible connection to melting of subducted basaltic 
crust. Thus, adakites and rocks with adakitic compositional signature probably have multiple origins.

In detail, the reported adakites from the Cook Island are generally thought to be formed by partial melting of eclogitic MORB, followed by limited interaction of the melt with the overlying mantle (>90\% MORB, <10\% mantle components), with little $(\leq 1 \%)$ participation of either subducted sediment or continental crust materials (Stern and Kilian, 1996). Thus, adakites in the Cook Island most prabably contain a lot of components of pristine adakite melt. On the other hand, Adak-type $\mathrm{Mg}$ (or high-Mg) andesites (i.e., the supposed type example of adakites) were produced by extensive reaction between melts from subducted slab and peridotite or basaltic melt in mantle wedge (Yogodzinski et al., 1994, 1995). These facts lead us to believe that there is a compositional gradation between a pristine adakitic and a primitive high-Mg andesitic melt. In addition, adakites and related rocks most probably contain, in different degrees, components of subducted sediment or continental crust (Stern and Kilian, 1996; Kay et al., 1993). Therefore, adakites and rocks with adakite-like geochemical signature comprise a series of rocks which are generated by mixture of at least three end-member components including melts from subducted slab, contributions from the peridotite mantle and contributions from subducted sediment or crustal materials.

\section{Components from subducted slab}

As mentioned earlier, the adakitic andesite and HMAs from the SCZ block show a lot of compositional characteristics that are similar to typical adakites. Thus, the major question concerns the origin of these rocks. The HMAs from the $\mathrm{SCZ}$ block have a relatively low $\mathrm{SiO}_{2}$ content (54-57\%), which argues against direct melting of mafic rocks in the lower crust, since melts generated by a moderate degree of partial melting of the mafic lower crust are felsic. Moreover, the adakitic andesite from the SCZ block has higher $\mathrm{SiO}_{2}$ content than the HMAs, but all the adakitic andesite and HMAs from the SCZ block have higher $\mathrm{Mg \#}$ than the rocks derived from melting of the lower crust in Cordillera (>52 vs. 29.3545.37 Mg\#-Atherton and Petford, 1993). Such a high $\mathrm{Mg} \#$ as well as high $\mathrm{Cr}$ and $\mathrm{Ni}$ of these rock most likely results from significant interaction of the original "silicic" melt with the mantle wedge. This argument was also used by Stern and Kilian (1996) to interpret origin of the adakites from the AVZ with high Mg\#, which were thought not to be derived by direct melting of the mafic lower crust. In addition, the high-Mg andesite-adakitic andesite-normal andesite rock association in the SCZ is identical to the rock association in the Klamath Mountain with adakitic signature that were thought to be generated by melting of the lower crust (Barnes et al., 1996).

The adakitic andesite has a steep LREE pattern and high $(\mathrm{La} / \mathrm{Yb})_{\mathrm{N}}$ (Fig. 2), which also make it hard to produce this rock through an AFC process because the accompanying basalts and normal andesite in the SCZ block do not have low HREE contents. More importantly, unlike the silicic rocks with adakite-like compositions that are generated through an AFC process (Castillo et al., 1999), the adakitic andesite and HMAs in the SCZ block have high $\mathrm{Cr}$ and $\mathrm{Ni}$ concentrations (higher than those in the basalts and normal andesites in the SCZ, see Table 1 and Fig. 4). These data suggest that the adakitic andesite and the HMAs could not be produced by differentiation from the basaltic and normal andesitic magma in the SCZ block. In addition, the volcanic rocks from the SCZ block, unlike the Camiguin rocks, do not display a successive compositional variation, and the adakitic andisites and HMAs form a compositional variation trend that is different from those of the basalts and normal andesites (Fig. 4). Moreover, the SCZ samples show a large isotopic compositional range (Fig. 6), indicating that they are most likely not derived from a homogeneous source. Therefore, it is very difficult to model the origin of the adakitic andesite and HMAs by AFC processes from a single parental magma that produced the basalts and normal andesites.

We argue that adakitic and high- $\mathrm{Mg}$ andesites from the SCZ block most probably contain com- 
ponents of adakitic melts from partial melting of subducted oceanic basalts or sediments; subsequently, the resulting melt could interact with the overlying mantle wedge. This is consistent with Kay's (1978) argument about the adakite from Aleutians. The high-Mg andesite from the SCZ block are not likely the products of direct partial melting of a mantle wedge (see below). They share some geochemical characteristics with typical adakites and are associated with adakitic andesite, indicating a close relation to an adakitic melt. Adakitic andesite from the SCZ block possesses all major and trace element signatures of typical adakite. Its $\mathrm{Y}, \mathrm{Yb}, \mathrm{La} / \mathrm{Yb}$ values as well as $\mathrm{Nd}, \mathrm{Pb}$ isotopic ratios are also much similar to those adakities from Aguilera area in N-AVZ that were thought to be related to slab melting (Stern and Kilian, 1996). Thus, these facts led us to believe that the adakitic and high-Mg andesites most probably have an amount of components from a subducted oceanic basalt.

\section{Origin of high-Mg andesite from the SCZ block}

Two models have been forwarded to interpret the origin of HMAs: (1) crystallization of primary magma from direct partial melting of a hydrous mantle (Tatsumi and Ishizaka, 1982; Tatsumi and Maruyama, 1989), and (2) interaction of ascending melts from partial melting of subducted slab with overlying mantle (Kelemen, 1990, 1995; Yogodzinski et al., 1994). The first model is based on some experiments indicating that HMAs can form via direct partial melting of the hydrous upper mantle under appropriate conditions $(\sim 1000$ $1150^{\circ}$ and $10-15 \mathrm{~kb}$-Tatsumi and Ishizaka, 1982; Hirose, 1997). These HMAs from direct partial melting of hydrous peridotite are expected to possess high $\mathrm{Mg}$ content or Mg\#, olivine phenocrysts and depleted isotopic features due to their equilibration with peridotite (Yogodzinski et al., 1994, 1995). However, the HMAs from the SCZ block do not have extremely high $\mathrm{Mg \#}$ and olivine phenocrysts, inferring they did not crystallized from a primary andesitic magma.

The major and trace elemental compositions of HMAs in the SCZ block are very similar to those of the well-known HMAs from the Setouchi and Cental Ryukyu region in the Japan (Shimoda et al., 1998; Shinjo, 1999). Although the Setouchi HMAs were originally thought to be typical primary magmas from the mantle wedge (Tatsumi and Ishizaka, 1982), more recent investigations suggest a different origin, i.e., initial melting of subducted sediments and subsequent interactions of such hydrous silicic melts with overlying mantle wedge (Shimoda et al., 1998). Shinjo (1999) interpreted that the geochemical signature of HMAs from Central Ryukyu resulted from a reaction between mantle peridotite and ascending melts derived from partial melting of the oceanic crust. Our sample from the SCZ block also most probably underwent such a process of mantle-melt interaction. We assume that adakitic melts (liquid) with relatively high $\mathrm{SiO}_{2}, \mathrm{Al}_{2} \mathrm{O}_{3}, \mathrm{La} / \mathrm{Yb}$ and low $\mathrm{MgO}$ from subducted slab ascended into the mantle wedge which has relatively low $\mathrm{SiO}_{2}$, $\mathrm{Al}_{2} \mathrm{O}_{3}, \mathrm{La} / \mathrm{Yb}$ and high $\mathrm{MgO}$. As a result of extensive interaction between adakitic melt and peridotite, the $\mathrm{MgO}$ content of the melt was elevated, but the $\mathrm{SiO}_{2}$ and $\mathrm{Al}_{2} \mathrm{O}_{3}$ contents as well as $\mathrm{La} / \mathrm{Yb}$ values were reduced. Because the mantle wedge is hotter than melt from slab melting, such a reaction most likely takes place. Kelemen (1990, 1995) used a simple reaction model between slabmelt and overlying peridotite to interpret why the average crust composition is close to that of HMA, and this interpretation was supported by experiment results. Carroll and Wyllie (1989) showed that the $\mathrm{SiO}_{2}$ content was decreased and the $\mathrm{MgO}$ content was largely increased in the melt due to the reaction between hydrous silicic melts and peridotite at $15 \mathrm{~kb}$. Of course, another possibility is that adakitic melt may mix with primary high$\mathrm{Mg}$ andesitic and/or basalic melt on their way to the surface to generate the HMAs. In either case, we consider that such processes are able to produce the compositional characteristics of both the HMAs and adakitic andesite in the SCZ block. The association of HMAs and adakitic andesite in the SCZ block and their geochemical affinity confirm that there is indeed a compositional gradation between a pristine adakitic melt and high-Mg 
andesitic magma. The adakitic andesite and high$\mathrm{Mg}$ andesites from the SCZ block were produced by interacting/mixing, to different extents, of an adakitic melt and mantle wedge/primary andesitic magma.

\section{A component from subducted sediment or conti- nental crust}

The melts from slab melting and its reaction with overlying peridotites is a likely scenario for producing the geochemical attributes of adakitic andesite and HMAs from the SCZ block, but their $\mathrm{Nd}$ and $\mathrm{Pb}$ isotopic ratios suggest a slightly different interpretation. The adakitic andesite and HMAs all show much lower $\varepsilon_{\mathrm{Nd}(350 \mathrm{Ma})}$ values (Fig. 6) than the MORB-type rocks from the ophiolitic block within the Mian-Lue belt, indicating the role of an enriched subduction component in the production of adakitic andesite and HMA magma. Their age-corrected $\mathrm{Nd}$ isotopic ratios (Table 2) are also clearly distinct from the high ${ }^{143} \mathrm{Nd} /{ }^{144} \mathrm{Nd}$ values of the adakites and HMAs in the Cook Island and western Aleutian regions that most probably contain components only from the mantle wedge and oceanic basalts (Stern and Kilian, 1996; Yogodzinski et al., 1995). These results lead us to believe that the component with enriched $\mathrm{Nd}$ isotopic feature such as crustal materials and/or subducted sediments were most probably involved in the generation of the adakitic andesite and HMA magma beneath the Mian-Lue subduction zone.

The adakitic andesite and HMAs from the SCZ block exhibit a relatively enriched Nd isotopic signature similar to that of the Setouchi HMAs except their relatively low age-corrected $\mathrm{Pb}$ isotopic ratios. Shimoda et al. (1998) suggested that subducting sediment could contribute significantly to the Setouchi HMA magma based on the radiogenic $\mathrm{Nd}, \mathrm{Pb}$ and $\mathrm{Sr}$ isotopic signature of the Philippine Sea sediment. Thus, it is possible that our samples also contain some subducted sediment components. However, unlike the Setouchi HMAs, the SCZ HMAs have relatively low $\mathrm{Al}_{2} \mathrm{O}_{3}(<15$ wt. $\%$ vs. $>15$ wt. $\% \mathrm{Al}_{2} \mathrm{O}_{3}$ for the Setouchi HMAs) and low age-corrected $\mathrm{Pb}$ isotopic ratios. Hence, sediment component involvement in the genera- tion of the SCZ adakitic andesite and HMAs is not likely as much as that in the generation of the Setouchi HMAs. On the other hand, an alternative explanation of the enriched $\mathrm{Nd}$ isotopic signature of the SCZ adakitic andesite and HMAs is related to the assimilation of the upper crust rocks. According to available data, the crustal basement rocks from upper crust in the Southern Qinling area also possess variable $\varepsilon_{\mathrm{Nd}(t)}$ values (-6.7 +5.5 , Huang and $\mathrm{Wu}, 1990$ ), which can be another low $\varepsilon_{\mathrm{Nd}(t)}$ mixing component. Thus, it is also possible that the adakitic andesite and HMA magmas are contaminated by such a high $\varepsilon_{\mathrm{Nd}(t)}$ end-member from of crustal material.

Therefore, in summary, we argue that adakitic andesite and HMAs from the SCZ block most probably contain components of adakitic melts from partial melting of the basaltic portion of the subducted slab. We also believe that the high $\mathrm{Cr}$, $\mathrm{Ni}$ contents and $\mathrm{Mg \#}$ indicate that the pristine adakitic melt interacted with the overlying mantle wedge. Finally, we argue that the adakitic andesite and HMAs were also most probably influenced to a certain extent by subducted sediment or by upper crustal material because of their enriched $\mathrm{Nd}$ isotopic signature. However, based on present data, we can not estimate with certainty the amount of sediment or crust material involved in the generation of our samples.

\section{Origin of basalts and normal andesites}

The normal andesites in the SCZ block are characterized by lower $\mathrm{Sr}$ and higher HREE and $\mathrm{Y}$ contents and lower $\mathrm{La} / \mathrm{Yb}$ values than the adakitic andesite and HMAs. They are very similar to normal orogenic andesite. For example, they show clear depletion in HFSE relative to $\mathrm{N}$ MORB. Hence, these normal andesites from the SCZ block are most likely the melting products of a hydrous mantle wedge which is similar to the source mantle of typical orogenic andesites. On the other hand, basalts in the SCZ block have a complex genesis, which is indicated by their variable REE abundance patterns and isotopic compositions. For example, basalt sample 093 shows a relatively flat REE pattern and high ${ }^{143} \mathrm{Nd} /{ }^{144} \mathrm{Nd}$ 
ratio, and thus is most likely derived from a hydrous harzburgite source in the mantle wedge. In contrast, basalt sample 014 has a rather enriched L-REE pattern and low ${ }^{143} \mathrm{Nd} /{ }^{144} \mathrm{Nd}$ ratios (if this isotopic data is reliable), suggesting that it was probably originated from a relatively enriched mantle wedge.

\section{Tectonic setting of the SCZ adakitic andesite and HMAs}

The HMAs have unique geochemical characteristics and restricted occurrence in modern island arcs. They generally occur in the forearc environment in the near-trench region. Although several different models for the origin of high-Mg andesite formation were forwarded (seen for example, discussion above), they all include two important factors: a hot and young oceanic lithosphere subducted and a hot mantle wedge (e.g., Shiraki et al., 1978; Meijer, 1980; Crawford et al., 1981; Tatsumi and Ishizaka, 1982). Owing to a high geothermal gradients in the mantle wedge resulting from recent back-arc basin opening and subduction of relatively young and hot oceanic lithosphere, hydrous peridotites at shallow levels in the subforearc mantle wedge may be partially melted to produce primary HMA magma (Tatsumi and Maruyama, 1989). On the other hand, the adakitic magma can also be derived directly from partial melting of a relatively young and hot oceanic crust that is being subducted (e.g., Peacock et al., 1994). Therefore, the same tectonic conditions are needed for either model of HMA and adakitic magma generation in the forearc. Our results hence suggest that both the adakitic andesite and HMA magma were probably formed in a paleo forearc setting.

\section{Implications for the Qinling orogenic evolution}

As mentioned above, the timing of final integration between the South and North China block (craton) has been controversial, e.g., middle Paleozoic (Gao et al., 1995) or Triassic (Zhang et al., 1995; Li et al., 1993). The adakitic andesite and HMAs found in SCZ block strongly suggest that an ancient volcanic arc occurred in the Mian-
Lue area. Meanwhile, those MORB-type ophiolites (Xu et al., 1998, 2000) also indicate that a paleo-oceanic basin existed at that time. Both the ocean basin and arc suggest that a paleo full oceanic-arc system might be present along paleoTethys subduction belt during the Late Paleozoic ( 350 Ma, Early Carboniferrous) in the Mian-Lue area of the Qinling Orogen. The paleo Tethyan ocean was a westward extension of the SuizhouJingshan Tethyan ocean in the southern side of Dabieshan belt (Dong et al., 1999) (Fig. 1), implying that the Mian-Lue paleo ocean was a part of the larger pelao-Tethyan ocean. Thus, the South China and North China blocks were still separated by the Mian-Lue paleo Tethyan ocean in the Late Paleozoic. This infers that the final integration of these two continental blocks took place after Carboniferous when the Mian-Lue paleo-Tethyan ocean disappeared. The collision time is most likely during the Triassic as is suggested by many collision and orogenic evidences recorded in Qinling area at that time (Li et al., 1993, 1996; Zhang et al., 1995, 1996). The recent study (Meng and Zhang, 1998) also supported above argument.

\section{CONCLUSION}

Adakitic andesite and HMAs have been recognized in the Sanchazi arc-block within the MianLue ophiolitic and tectonic melange of the Qinling Orogen. Although all igneous rock from this block are highly enriched in LILEs and depleted in HFSE that are typical for subduction-zone lava, the adakitic andesite and HMAs have geochemical characteristics different from the normal andesites and basalts. The adakitic andesite from the SCZ block is characterized by the steep REE patterns, low $\mathrm{Y}$ and high $(\mathrm{La} / \mathrm{Yb})_{\mathrm{N}}$ that are typical of adakites. The HMAs from the SCZ block also have adakitic affinities except for the lower $\mathrm{La} / \mathrm{Yb}$ ratio and $\mathrm{Al}_{2} \mathrm{O}_{3}$ content. In addition, both the adakitic andesite and HMAs show a relatively enriched $\mathrm{Nd}$ isotopic signature, suggesting that they contain a little component from sediment or crustal materials. Our data reveal that adakitic andesite and HMAs in the SCZ block were not 
generated by direct melting of mafic rocks in the lower crust or through an AFC process of a basaltic magma. It is most likely that these adakitic andesite and HMAs were produced by a series of events, starting with partial melting of an eclogitic subducted basalt or sediment, followed by interaction of the melt generated with the overlying mantle wedge, and/or finally assimilation with upper level crustal materials.

A full paleo ocean-arc system was present in the Mian-Lue area of the Qinling Orogen during the Late Paleozoic. The South China and North China blocks were still separated by the Mian-Lue paleo Tethyan ocean at that time. Thus, our results are in favor of the argument-it is in the Triassic that final integration occurred between the South China and North China block (craton).

Acknowledgments - We sincerely acknowledge Dr. Y. Orihashi and G. Yogodzinski for their constructive review to significantly improve the paper. Special thanks are due to Dr. P. Castillo for his helpful suggestions and comments. Finally we also express our gratitude to Dr. Y. Tatsumi and R. Shinjo for their helpful comments of an earlier version of this manuscript. Financial support for this research was provided by the Major State Basic Research Program of People's Republic of China (No. G1999043202), China NSF grand (No. 49603045) and the National Climbing program of China (No. 95-Y-25).

\section{REFERENCE}

Arculus, R. J. (1994) Aspects of magma genesis in arcs. Lithos 33, 189-208.

Atherton, M. P. and Petford, N. (1993) Generation of sodium-rich magmas from newly underplated basaltic crust. Nature 362, 144-146.

Barnes, C. G., Petersen, S. W., Kistler, R. W., Murray, R. and Kays, M. A. (1996) Source and tectonic implications of tonalite-trondhjemite magmatism in the Klamath Mountains. Contrib. Mineral. Petrol. 123, 40-60.

Bienvenu, P., Bougault, H., Joron, M. and Dmitriev, L. (1990) MORB alteration: rare-earth element/nonrear-earth hygromagmaphile element fractionation. Chem. Geol. 82, 1-14.

Carroll, M. R. and Wyllie, P. J. (1989) Experimental phase relations in the system tonalite-peridotite- $\mathrm{H}_{2} \mathrm{O}$ at $15 \mathrm{~kb}$ : implications for assimilation and differen- tiation processes near the crust-mantle boundary. $J$. Petrol. 30, 1351-1382.

Castillo, P. R., Janney, P. E. and Solidum, R. U. (1999) Petrology and geochemistry of Camiguin island, southern Philippines: insights to the source of adakites and other lavas in a complex arc setting. Contrib. Mineral. Petrol. 134, 33-51.

Cheng, Q., Park, K. H., Macdougall, J. D., Zindler, A., Lugmair, G. W., Hawkins, J., Lonsdale, P. and Staudigel, H. (1987) Isotopic evidence for a hot spot origin of the Louisville seamount chain. Seamounts, Island and Atolls (Keating, B., Fryer, P., Batiza, R. and Boechlert, G., eds.), Am. Geophys. Union Monogr. 43, 283-296.

Crawford, A. J., Beccaluva, L. and Serri, G. (1981) Tectono-magmatic evolution of the West PhilippineMariana region and the origin of boninites. Earth Planet. Sci. Lett. 54, 346-356.

Crawford, A. J., Falloon, T. J. and Green, D. H. (1989) Classification, petrogenesis and tectonic setting of boninites. Boninites and Related Rocks (Crawford, A. J., ed.), 1-49, Unwin Hyman, London.

Defant, M. J. and Drummond, M. S. (1990) Derivation of some modern arc magmas by melting of young subducted lithosphere. Nature 347, 662-665.

Defant, M. J. and Drummond, M. S. (1993) Mount St. Helens: Potential example of the partial melting of the subducted lithosphere in a volcanic arc. Geology 21, 547-550.

Dong, Y.-P., Zhang, G.-W., Lai, S.-C., Zhou, D.-W. and Zhu, B.-Q. (1999) An ophiolitic tectonic melange first discovered in Huashan area, South margin of Qinling orogenic belt, and its tectonic implications. Science in China (Series D) 43(3), 292-302.

Drummond, M. S. and Defant, M. J. (1990) A model for trond-hjemite-tonalite-dacite genesis and crustal growth via slab melting: Archean to modern comparisons. J. Geophys. Res. 95, 21503-21521.

Feng, Q.-L., Du, Y.-S., Yin, H.-F., Shen, J.-H. and Xu, J.-F. (1996) Carboniferous radiolarian fauna firstly discovered in Mian-Lue ophiolitic melange belt of South Qinling Mountains. Science in China (Series D) 39 (Supp.), 87-92.

Gao, S., Zhang, B.-R., Gu, X.-M., Xie, X.-L., Gao, C.-L. and Guo, X.-M. (1995) Silurian-Devonian provenance changes of South Qinling basin: implications for accretion of the Yangtze (South China) to the North China Craton. Tectonophysics 250, 183-197.

Gill, J. B. (1981) Orogenic Andesite and Plate Tectonics. Springer, Berlin, 390 pp.

Huang, X. and Wu, L.-R. (1990) Nd-Sr isotopes of granitoids from Shanxi province and their significance for tectonic evolution. Acta Petrologica Sinica 6, 1-11 (in Chinese with English abstract). 
Hirose, K. (1997) Melting experiments on Iherzolite KLB-1 under hydous conditions and generation of high-magnesian andesitic melts. Geology 25, 42-44.

Kay, R. W. (1978) Aleutian magnesian andesites: melts from subducted Pacific Ocean crust. J. Volcanol. Geotherm. Res. 4, 117-132.

Kay, S. M., Ramos, V. A. and Marquez, M. (1993) Evidence in Cerro Pampa volcanic rocks for slab-melting prior to ridge-trench collision in Southern south American. J. Geol. 101, 703-714.

Kelemen, P. B. (1990) Reaction between ultramafic rock and fractionating basaltic magma: I. Phase relations, the origin of calc-alkaline magma series, and the formation of discordant dunite. J. Petrol. 31, 5198.

Kelemen, P. B. (1995) Genesisof high Mg\# andesites and the continental crust. Contrib. Mineral. Petrol. 120, 1-19.

Kushiro, I. (1990) Partial melting of mantle wedge and evolution of Island Arc crust. J. Geophys. Res. 95, 15929-15939.

Lai, S.-C., Zhang, G.-W., Yang, Y.-C. and Chen, J.-Y. (1998) Geochemistry of the ophiolite and island arc volcanic rock in the Mianxian-Lueyang suture zone, Southern Qinling and their tectonic significance. Geochemica 27, 283-293 (in Chinese with English abstract).

Li, S.-G., Chen, Y., Cong, B.-L., Zhang, R., Liou, D., Hart, S. R. and Ge, N. (1993) Collision of the North China and Yangtze blocks and formation of coesitebearing eclogites: timing and processes. Chem. Geol. 109, 70-89.

Li, S.-G., Sun, W.-D. and Zhang, G.-W. (1996) Chronology and geochemistry of metavolcanic rocks from Higouxia valley in Mian-Lue tectonic belt, South Qinling evidence for a Paleozoic oceanic basin and its close time. Science in China (Series D) 39, 300310 .

Li, X.-H. (1997) Geochemistry of the Longsheng Ophiolite from the southern margin of Yangtze Craton, SE China. Geochem. J. 31, 323-337.

Li, X.-H. and McCulloch, M. T. (1998) Geochemical characteristics of Cretaceous mafic dikes from Northern Guangdong, SE China: age, origin and tectonic significance. Mantle Dynamics and Plate Interactions in East Asia Geodynamics (Flower, M. F. J. et al., eds.), The American Geophysical Union, 27, 405419, Washington.

Ludden, J. N. and Thompson, G. (1978) Behavior of rare earth elements during submarine weathering of tholeiitic basalts. Nature 274, 147-149.

Mahoney, J. J., Frei, R., Tejada, M. L. G., Mo, X. X., Leat, P. T. and Nagler, T. F. (1998) Tracing the Indian Ocean mantle domain through time: isotopic results from old west Indian, east Tethyan, and South Pacific seafloor. J. Petrol. 39, 1285-1306.

McCulloch, M. T., Gregory, R. T., Wasserburg, G. J. and Taylor, H. T. (1981) Sm-Nd, Rb-Sr, and 18O/ 160 isotopic systematics in an oceanic crustal section: evidence from the Samail ophiolites. J. Geophys. Res. 86, 2721-2735.

Meijer, A. (1980) Primitive arc volcanism and a boninite series: examples from western Pacific island arcs. Tectonic and Geologic Evolution of Southeast Asian Seas and Islands (D. E. Hayes, ed.), Am. Geophys. Union Monogr. 23, 269-282.

Meng, Q.-R. and Zhang, G.-W. (1998) Timing of collision of the North and South China blocks: Controversy and reconciliation. Geology 27, 123-126.

Peacock, S. M., Rushmer, T. and Thompson, A. B. (1994) Partial melting of subducting oceanic crust. Earth Planet. Sci. Lett. 121, 227-244.

Rogers, G., Saunders, A. D., Terrell, D. J., Verma, S. P. and Marrinet, G. F. (1985) Geochemistry of Holocene volcanic rocks associated with ridge subduction in Baja California, Mexico. Nature 315, 389-392.

Saunders, A. D., Rogers, G., Marrinet, G. F., Terrell, D. J. and Verma, S. P. (1987) Geochemistry of Cenozoic volcanic rocks, Baja California, Mexico: implications for the petrogenesis of post-subduction magmas. J. Volcanol. Geotherm. Res. 32, 223-245.

Shimoda, G., Tatsumi, Y., Nohda, S., Ishizaka, K. and Jahn, B. M. (1998) Setouchi high-Mg andesites revisited: geochemical evidence for melting of subducting sediments. Earth Planet. Sci. Lett. 160, 479-492.

Shinjo, R. (1999) Geochemistry of high Mg andesites and the tectonic evolution of the Okinawa TroughRyukyu arc system. Chem. Geol. 157, 69-88.

Shiraki, K., Kuroda, N., Maruyama, S. and Urano, H. (1978) Evolution of the Tertiary volcanic rocks in the Izu-Mariana arc. Bull. Volcanol. 41, 548-562.

Stern, C. R. and Kilian, R. (1996) Role of the subducted slab, mantle wedge and continental crust in the generation of adakites from the Andean Austral volcanic zone. Contrib. Mineral. Petrol. 123, 263-281.

Sun, S.-S. and McDonough, W. F. (1989) Chemical and isotopic systematic of oceanic basalts: implications for mantle composition and processes. Magmatism in the Ocean Basin (Saunders, A. D. and Norry, M. J., eds.), Geol. Soc. Sp. Publ. 42, 313-345.

Tatsumi, Y. and Ishizaka, K. (1982) Origin of high magnesian andesites in the Setouchi volcanic belt, southwest Japan: I. Petrographical and chemical characteristics. Earth Planet. Sci. Lett. 60, 293-304.

Tatsumi, Y. and Maruyama, S. (1989) Boninites and high-Mg andesites: tectonics and petrogenesis. Boninites and Related Rocks (Crawford, A. J., ed.), 
50-71, Unwin Hyman, London.

Todt, W., Cliff, R. A., Hanzer, A. and Hofmann, A. W. (1984) ${ }^{202} \mathrm{~Pb}+{ }^{205} \mathrm{~Pb}$ double spike for lead isotopic analysis. Terra Cognita 4, 209.

Wang, Q., Xu, J.-F., Wang, J.-X., Zhao, Z.-H., Qiu, J.-X., Wang, R.-J., Xiong, X.-L., Sang, L.-K. and Peng, L.-H. (2000) The recognition of adakite-type gneisses in the North Dabie Mountains and its implication to ultrahigh pressure metamorphic geology. Chinese Science Bulletin 45(21), 1927-1933.

Winchester, J. A. and Floyd, P. A. (1976) Geochmical magma type discrimination: application to altered and metamorphosed basic igneous rocks. Earth Planet. Sci. Lett. 28, 459-469.

$\mathrm{Xu}$, J.-F. and Han, Y.-W. (1996) High radiogenic Pbisotope composition of ancient MORB-type rocks from Qinling area: Evidence for the presence of Tethyan-type oceanic mantle. Science in China (Series D) 39 (Supp.), 33-42.

Xu, J.-F., Zhang, B.-R. and Han, Y.-W. (1994) Recognition of ophiolite belt and granulite in Northern Area of Mian-Lue, Southern Qinling, China and their implication. Journal of China University of Geoscience 5, 25-27.

Xu, J.-F., Yu, X.-Y., Li, X.-H., Han, Y.-W., Shen, J.-H. and Zhang, B.-R. (1998) The Discovery of the High Depleted N-MORB-type Volcanic Rocks: New Evidence for Paleo Ocean of Mian-Lue. Chinese Science Bulletin 43(6), 510-514.

Xu, J.-F., Castillo, P. R., Li, X.-H., Yu, X.-Y., Zhang,
B.-R. and Han, Y.-W. (2000) Paleo-Tethyan MianLueyang Northern Ophiolite in the Qinling Mountains, Central China: Implications for the source of the low ${ }^{206} \mathrm{~Pb} /{ }^{204} \mathrm{~Pb}$ mantle components in the Indian Ocean. Earth Planet. Sci. Lett. (submitted).

Yogodzinski, G. M. and Kelemen, P. B. (1998) Slab melting in the Aleutians: implicatioms of an ion probe study of clinopyroxene in primitive adakite and basalt. Earth Planet. Sci. Lett. 158, 53-65.

Yogodzinski, G. M., Volynets, O. N., Koloskov, A. V., Seliverstov, N. I. and Matvenkov, V. V. (1994) Magnesian andesites and the subduction component in a strongly calc-alkaline series at Piip Volcano, far western Aleutians. J. Petrol. 35, 163-204.

Yogodzinski, G. M., Kay, R. W., Volynets, O. N., Koloskov, A. V. and Kay, S. M. (1995) Magnesian andesite in the western Aleutian Komandorsky region: implication for slab melting and processes in the mantle wedge. Geol. Soc. Am. Bull. 107, 505519.

Zhang, G.-W., Meng, Q.-R. and Lai, S.-C. (1995) Tectonics and structure of Qinling Orogenic belt. Science in China (Series B) 38, 1379-1394.

Zhang G.-W., Meng, Q.-R., Yu, Z.-P., Sun, Y., Zhou, D.-W. and Guo, A.-L. (1996) Orogenic processes and dynamics of the Qinling. Sciences in China 39, 225234.

Zindler, A. and Hart, S. R. (1986) Chemical geodynamics. Ann. Rev. Earth Planet. Sci. 14, 493571 . 